\title{
JEZZYKOZNAWSTWO
}

Jolanta Chomko

DOI 10.15290/sw.2018.18.05

Uniwersytet w Białymstoku

Wydział Filologiczny

Instytut Filologii Wschodniosłowiańskiej

tel. +48857457450

e-mail: jchomko@interia.pl

ORCID ID: https://orcid.org/0000-003-0289-7221

\section{Paleta barw achromatycznych w Szkartatnych żaglach Aleksandra Grina}

Słowa kluczowe: Grin, idiolekt pisarza, semantyka barw, barwy achromatyczne

\section{Wstęp}

Przedmiotem analizy niniejszego artykułu są nazwy barw achromatycznych występujące w feerii Szkartatne żagle Aleksandra Grina. W tym utworze, napisanym w latach 1920-1921, autor próbuje zbudować filozofię twórczej roli marzenia i bajki w realizacji konkretnego życia. Na magię i siłę oddziaływania tej powieści na czytelnika zwraca uwagę Konstanty Paustowski, biograf pisarza: „В чем сила этой книги? Прежде всего - в ее редчайшей поэтичности. Прочитав ее, как бы получаешь в лицо фантастический залп, заряд, но не порохового дыма, а целебного воздуха морей и цветов, лесных дебрей и трав. (...) Да, со страниц этой книги получаешь заряд свежего ветра, ясного воздуха, сияния облаков. Погружаешься в мир людей привлекательных и на первый взгляд порой странных. Почти все они отличаются одной общей для них чертой - бесхитростной человечностью, отвагой и жаждой нового" [http://paustovskiy.niv.ru/ paustovskiy/public/volshebnik-o-grine.htm].

Cała twórczość A. Grina, a tym samym analizowane dzieło, zdaniem Seweryna Pollaka, „zajmuje we współczesnej literaturze rosyjskiej pozycję 
wyjątkową. Jest ona właściwie nieporównywalna w swej odrębności i dziwności i trudno dla niej w tej literaturze znaleźć jakikolwiek bezpośredni odpowiednik. Jest tak odrębna i tak inna, jak inne i niezwykłe było życie jej autora" [Pollak 1959, V].

Aleksander Grin to pisarz, który jest „живописцем, воспринимающим и отражающим мир многоцветно, который создает свой мир, «говорящий» и значимый, подчиненный определенным закономерностям авторского творчества" [Мельникова 2009, 64]. Pole semantyczne nazw kolorów w Szkartatnych żaglach zarysowuje się dość wyraźnie, autor wykorzystuje zarówno barwy podstawowe, jak i niepodstawowe. Część nazw barw jest bezpośrednio związana z tytułem feerii, w związku z czym często pojawiają się przymiotniki альй і красный. Najbardziej liczną grupę kolorystyczną w tym utworze stanowi czerwien. Pozostałe pola barw są reprezentowane znacznie rzadziej.

\section{Barwy achromatyczne}

Do barw achromatycznych zaliczamy te barwy, które nie posiadają dominanty barwnej, a więc białą, czarną oraz wszystkie stopnie szarości. Barwy te inaczej nazywane są niekolorowymi. Chociaż system barw w różnych językach rozwijał się inaczej, to jego historia ma wiele uniwersersalnych cech wspólnych. Autorzy pierwszego opracowania dotyczącego semantyki barw B. Berlin i P. Kay, po przeanalizowaniu leksyki kolorystycznej prawie stu języków stwierdzili, że w pierwszym stadium ewolucji leksykonu barw występują tylko dwie podstawowe nazwy barw, oznaczające pojęcia 'czarny' i 'biały' [Berlin, Kay 1969, 22-23]. Barwy biała i czarna pełnią również funkcję pomocniczą w stosunku do innych kolorów - powodują ich rozjaśnienie lub przyciemnienie (przy pomocy bieli i czerni można stworzyć np. kolor jasnoniebieski - 'niebieski rozjaśniony bielą' czy ciemnoczerwony - 'czerwony przyciemniony czernią'). Z kolei barwa szara jest uzyskiwana przez połączenie barw dopełniających i „dookreśla kolor pod względem ilości światła jako pośredni między jasnością i ciemnością" [Komorowska 2010, 83].

\section{Barwa czarna (черный цвет)}

W związku z tym, że barwa czarna należy do barw achromatycznych i jest pozbawiona dominanty barwnej, w pracach leksykograficznych jest interpretowana poprzez porównanie $\mathrm{z}$ jakimiś przedmiotami. W słowniku 
języka rosyjskiego pod red. S. A. Kuzniecowa semantyka koloru czarnego jest wyjaśniana poprzez kolor sadzy i węgla ${ }^{1}$.

Czerń to symbol śmierci, chaosu, mroku i nocy, to kolor żałoby. Barwa ta $\mathrm{w}$ historii światowych cywilizacji jest łączona tylko ze zjawiskami negatywnymi, m.in. z czarną magią, światem podziemnym, jak również z piekłem. Barwy czarna i biała symbolizuja przeciwstawność dwóch światów, dwóch składowych istoty ludzkiej, dwóch duchowych istot [http://www.rulit.me/ books/simvoly-znaki-emblemy-enciklopediya-read-228708-198.html]. Поскольку черный поглощает все другие цвета, он выражает отрицание и отчаяние, является противостоянием белому, обозначает негативное начало. Символ потусторонности, инфернальности» [Шейнина 2003, 367-368]. Niewątpliwie, te symbole kulturowe powinny zostać odzwierciedlone w twórczości każdego pisarza, jednak idiolekt zawiera nie tylko symbolikę ogólną i narodową, ale również spojrzenie na świat autora. Każdy pisarz odbiera i przedstawia na swój sposób.

Najciemniejsza barwa achromatyczna nazywana jest w Szkarlatnych $\dot{z} a-$ glach przymiotnikiem черныци (21) i imiesłowem почерневший (1). Od razu nasuwa się spostrzeżenie, że w tak optymistycznym utworze autor tak często wykorzystuje barwę posiadającą mroczną symbolikę. Jednak należy zwrócić uwage na fakt, że na poziomie tekstu w idiolekcie pisarza symbolizm może mieć zupełnie inny charakter. Jest to widoczne również w symbolice barwy czerwonej, która wyraźnie różni się od symboliki narodowej ${ }^{2}$.

Okazuje się, że w większości użyć nazwa barwy czarnej nie odgrywa żadnej roli symbolicznej. A. Grin używa nazw czerni na ogół w sposób konwencjonalny, wykorzystując je do kreacji świata przedstawionego.

Badany materiał pokazuje, że stosunkowo często czerń jest wykorzystywana do opisu przyrody. Autor przy jej pomocy opisuje wodę: На черной дали легла уже трепетная снежная белизна, пена блестела, и багровый разрыьв, вспьхнув средь золотой нити, бросил по океану, к ногам Ассоль, алую рябь (AР, 60), Лонгрен выходил на мостик, настланный по длинным рядам свай, где, на самом конце этого дощатого мола, подолгу курил задуваемую ветром трубку, смотря, как обнаженное у берегов дно дымилось седой пеной, еле поспевающей за валами, грохочущий бег которых к черному, штормовому горизонту на-

\footnotetext{
1 черный 'самый темный из всех цветов, имеющий цвет сажи, угля' [Большой толковый словарь русского языка 2000, 1474].

2 Por.: J. Chomko, Semantyka i przektad wybranych nazw barw w „Szkarlatnych żaglach” Aleksadra Grina (pole czerwieni), Słupsk (złożone do druku).
} 
полнял пространство стадами фантастических гривастых существ, несущихся в разнузданном свирепом отчаянии $\kappa$ далекому утешению (AР, 11), Была полная ночь; за бортом в сне черной воды дремали звезды и огни мачтовых фонарей (AР, 41), Стальной у берега ивет спящего океана переходил в синий и черный (AP, 59). Warto zwrócić uwagę na fakt, że jest to najczęściej opis koloru wody w morzu nocą, w momencie, kiedy nie występuje światło, kiedy promienie słoneczne jej nie rozświetlają. W tych opisach czerń nawiązuje do swojego symbolu - ciemności, nocy.

Kolor czarny zostaje przywołany również w opisach roślin. W Szkarlatnych żaglach pojawiają się tulipany o nietypowym dla tej rośliny kolorze: Лучшие сорта тюльпанов серебристо-голубьх, фиолетовьх, и черных с розовой тенью - извивались в газоне линиями прихотливо брошенных ожерелий (AP, 26) oraz drzewo hebanowe, które ze względu na swój kolor w języku rosyjskim nosi nazwę „черное дерево": Оно заключено в бочки черного дерева, крепкого, как желеоз (AР, 28), Но он охотно грузил фрукты, фарфор, животных, пряности, чай, табак, кофе, ченные породы деревьев: черное, сандал, пальму (АР, 67).

W nielicznych opisach czerń uczestniczy w kreowaniu obrazów człowieka. Została ona wykorzystana do opisu wyglądu sprzedawcy w sklepie z artykułami dziecięcymi, do którego Assol zaniosła zabawki wykonane przez јеј ојса: Ну-с, прихожу в большой магазин; там куча народа. Меня затолкали; однако я выбралась и подошла к черному человеку в очкax (AP, 52) oraz węglarzy, których dziewczynka obdarzyła bardzo dużym zaufaniem: Она медленно осмотрела поляну под вязом, где стояла телега,зеленую в розовом вечернем свете траву, черных молчаливых угольщиков (AР, 75), Она взяла огромную черную руку и привела ее в состояние относительного трясения (AP, 75). W tym drugim przypadku przymiotnik черный może wskazywać nie tylko na kolor skóry, ale też na zabrudzenia ciała spowodowane wykonywanym zawodem. Takiej sytuacji leksem черный jest synonimem leksemu грязный.

$\mathrm{W}$ analizowanej powieści barwa czarna incydentalnie występuje również w opisach strojów - kapitana i matki Greya. Na obrazie, wiszącym w bibliotece w domu Greya, przedstawiony został marynarz w bogatym stroju z czarną szpadą: Завернутые поль его кафтана трепались ветром; белая коса и черная шпага вытянуто рвались в воздух (AP, 35). W drugim przypadku kolor czarny pełni symboliczną rolę. Matka Greya modli się w czarnej sukience, symbolizującej niewątpliwie żałobę i smutek. Ten ubiór odzwierciedla uczucia kobiety, która po ucieczce z domu syna i śmierci męża 
prowadzi samotne życie: Ему сказали, где мать; он прошел в высокое помещение и, тихо прикрьв дверь, несльшно остановился, смотря на поседевшую женщину, в черном платье (AP, 39).

Kolor czarny został również wykorzystany przez pisarza do kreacji otoczenia człowieka. Współtworzy on między innymi opisy rodzinnego domu Greya - biblioteki i znajdujących się tam książek: Tам - раскрьıтьий альбом с вьцкользнувшими внутренними листами, там - свитки, перевязаннье золотыл шнуром; стопь книг угрюмого вида; толстье пластьл рукописей, насьпь миниатюрных томиков, трещавших как кора, если их раскрьввали; здесь - чертежи и таблицьи, рядьи новых изданий, картыл; разнообразие переплетов, грубых, нежных, черных , пестрых, синих, серых, толстых, тонких, шершавых и гладких (AР, 34) огаz kuchni: B суровом молчании, как жрецьл, двигались повара; их белье колпаки на Фоне почерневших стен придавали работе характер торжественного служения (AP, 30).

W analizowanym materiale językowym niewiele jest przykładów, w których A. Grin zastosował przymiotnik черныци w opisie budynków. Ma to miejsce tylko w przypadku dachu szynku w Kapernie: - Должно бьтьь, вон та черная крылиа, - сообразил Летика, - а, впрочем, может, и не она. (AP, 47) i okna, przez które o poranku zaczyna wpadać do pokoju Assol światło: Низ окна был черен; верх просветлел. Извне дома, почти на краю рамьи, блестела утренняя звезда (AР, 57).

Rzadkim zjawiskiem w analizowanym utworze jest pojawienie się zwierząt. Do przedstawienia obrazu jednego z nich - psa, którego Assol spotyka za wsią, została wykorzystana czerń: Там, где дорога кончилась, переходя в глухую тропу, у ног Ассоль мягко завертелась пушистая черная собака с белой грудью и говорящим напряжением глаз (AP, 58).

W Szkarłatnych żaglach nazwa barwy czarnej odgrywa również symboliczną rolę. Jej negatywność wyrażona została w obrazie „czarnej zabawki”, którą „zrobił” Longren dla swojego przyjaciela Mennersa, kiedy nie pomógł mu uratować się podczas sztormu. Po powrocie do domu po tym wydarzeniu Longren mówi do córki: - Черную игрушку я сделал, Ассоль, - cnu! (AP, 12).

W utworze jest także mowa o czarnych flagach piratów, które nawiązują do ,zbrukanych, drapieżnych, potarganych, brutalnych żagli” (AP, 31), które są przeciwstawiane szkarłatnym żaglom. W tych przykładach barwa czarna konotuje takie cechy jak zło, drapieżność, zabijanie: Бbıлu maм еще корабли-пиратьл, с черньлм Флагом и страшной, размахивающей ножами командой; корабли-призраки, сияюшие мертвенным светом синего озарения (AР, 36), «Пантен, тебя озадачили. Не хочет ли он 
попробовать контрабанды? Не вступаем ли мы под черным флагом nupama»? (AP, 62).

Czerń występuje również w opisach statków, pojawia się w opisie masztu statku, cumujaccego wieczorem, kiedy nie ma światła w porcie Dubel: Пpoшло еще мало времени, и в порте Дубельт вечерняя звезда сверкнула над черной линией новой мачты (AР, 40).

Negatywne konotacje wywołuje również przymiotnik черный użyty w opisie niewywołanego żadna przyczyną smutnego nastroju Greya: Eщe утром, едва проснувшись, он уже почувствовал, что этот день начался в черных лучах (AР, 41)

\section{Barwa biała (белый цвет)}

W słowniku opisowym języka rosyjskiego kolor biały definiowany jest jako kolor śniegu, mleka i kredy³ . Biel to kolor życia, czystości, radości i prostoty, to symbol słońca, powietrza, świętości i zbawienia. Kolor ten oznacza jasną porę dnia, czas pracy i dobrych uczynków, symbolizuje absolutny brak przeszkód, rozwiązanie problemów i nowy początek [Шейнина 2003, 359]. W związku z tym, że nie posiada barwnej dominanty, wyraża niewinność i prawdę, symbolizuje też umiarkowanie [http://www.rulit.me/books/sim voly-znaki-emblemy-enciklopediya-read-228708-24.html].

Nazwy bieli, występujące w Szkarłatnych żaglach, to бельий (19), белизна (3) oraz - marginalnie - przymiotniki: белокурый (1), серебряный ${ }^{4}$ (1) i imiesłów белевший (1).

Analiza zgromadzonego materiału wykazała, że najczęściej biel jest wykorzystywana przez Grina do opisu wyglądu zewnętrznego człowieka. Dotyczy to zarówno jego ciała, jak i odzieży. W powieści barwa biała została zastosowana do opisu koloru skóry głównych bohaterów - Greya: Tемные, с оттенком грустного вопроса глаза казались несколько старше лица; его неправильный мягкий овал был овеян того рода прелестным

3 бельй - 'цвета снега, молока, мела' [Большой толковый словарь русского языка 2000, 70].

4 Jak zauważa Ryszard Tokarski, barwa srebrna jest niepodstawową nazwą przyporządkowaną bieli. Kolorystyczne określenie srebrny posiada „swoisty odcień metalicznego połysku, nie gubiąc jednocześnie związku z bielą". Związek ten można zauważyć zarówno w etymologicznym pokrewieństwie nazw 'bieli' i 'srebra' w wielu językach indoeuropejskich, jak i w perceptualnym podobieństwie poświadczonym materiałem leksykalnym i faktami pozajęzykowymi [Tokarski 2004, 70-71]. "Srebrny to kolor fizycznie bliski białemu" [tamże, 73]. 
загаром, какой присущ здоровой белизне кожи (AP, 20) i Assol: Он бережно опустил кольцо на мальй мизинеи, белевший из-под затьлка (AР, 46), Ее волось сдвинулись в беспорядке: у шеи расстегнулась пуговица, открьвв белую ямку (AP, 45). W przypadku opisu młodej dziewczyny barwa biała oddaje delikatność kobiecego ciała, nawiązając jednocześnie do swego symbolu - niewinności. Wyrazy określające kolor biały posłużyły autorowi również do opisu koloru włosów: Завернутьле nоль его кафтана трепались ветром; белая коса и черная шпага вытянуто рвались в воздух (AP, 35), Но он уже навсегда запомнил тот короткий грудной смех, полный сердечной музыки, каким встретили его дома, и раза два в год посещал замок, оставляя женщине с серебряньми волосами нетвердую уверенность в том, ито такой большой мальчик, пожалуй, справится с своими игрушками (AP, 40), - A что скрыввается в моем «тур-люр-лю»? - спросил подошедиий Флейтист, росльй детина с бараньими голубыми глазами и белокурой головой (AP, 65).

Przymiotnik бельй współtworzy także opisy odzieży: koszuli - Ceдье кудри складками вьппадли из-под его соломенной шляпь; серая блуза, заправленная в синие брюки, и вьсокие сапоги придавали ему вид охотника; бельй воротничок, галстук, пояс, унизанный серебром блях, трость и сумка с новеньким никелевым замочком - вьказывали горожанина (AP, 20), czapek kucharskich - В суровом молчании, как жрець, двигались повара; их белье колпаки на фоне почерневших стен придавали работе характер торжественного служения (AP, 30), sukienki - За ореховой рамой в светлой nyстоте отраженной комнаты стояла тоненькая невысокая девушка, одетая в дешевыий бельий муслин с розовьлми иветочками (AP, 54) oraz rękawiczek od munduru - Пантен, крича как на пожаре, вывел "Секрет» из ветра; судно остановилось между тем как от крейсера помчался паровой катер с комадой и лейтенантом в бельх перчаткаx (AP, 78).

Barwa biała w analizowanym utworze uczestniczy w kształtowaniu językowych obrazów przyrody. Została ona wykorzystana do opisu przestrzeni ziemskiej - piasku, który swoją jasnością kontrastuje z ciemnymi kilami: Рьбачьи лодки, повытащенные на берег, образовали на белом песке ряд темных килей, напоминающих хребты громадных рыб (AР, 10), kamieni, które leżą na dnie przeźroczystego strumienia: Отойдя в лес за мостик, по течению ручья, девочка осторожно спустилась на воду у самого берега пленившее ее судно; паруса тот час сверкнули альм отражением в прозрачной воде; свет, прнизывая материю, лег дро- 
жашим розовым излучением на бельх камнях дна (AP, 17) oraz nieba obłoków: За золотой нитью небо, вспьхивая, сияло огромнылм веером света; белье облака тронулись слабым румянцем (АР, 59).

Jednym z elementów krajobrazu, opisywanym przy pomocy bieli, jest też woda. Kolor ten został zastosowany w opisie oceanu w dwóch przeciwstawnych porach dnia - o świcie: На черной дали легла уже трепетная снежная белизна, пена блестела, и багровый разрыв, вспьхнув средь золотой нити, бросил по океану, к ногам Ассоль, алую рябь (AР, 60), i wieczorem: Струя пеньl, отбрасыьваемая кормой корабля Грэя «Секрет», прошла через океан белой чертой и погасла в блеске вечерних огней Лисса (АР, 40).

Barwy z pola semantycznego bieli sporadycznie pojawiają się w opisach roślin i zwierząt. Są to jednokrotnie poświadczone w tekście użycia: $B$ cnoкойно тяготеющей крупной листве каштанов стояли белье шишки иветов, их аромат мешался с запахом росы и смольи (АР, 59), Там, где дорога кончилась, переходя в глухую тропу, у ног Ассоль мягко завертелась пушистая черная собака с белой грудью и говоряшим напряжением глаз (AР, 58).

Leksem бельй występuje także w opisie dnia, a dokładniej - poranka, gdzie oznacza 'jasny, oświetlony przez słońce’: Былл бельй утренний час; в огромном лесу стоял тонкий пар, полньй странных видений (AР, 76).

Biel została wykorzystana do opisu okrętów - zarówno zabawki, którą wykonał Longren: Одна такая новинка была миниатюрной гоночной яхтой; белое суденышко это несло алье паруса, сделанные из обрезков шелка, употреблявшегося Лонгреном для оклейки пароходных кают - игрушек богатого покупателя (AP, 16), jak i okrętu Greya, na który z nadzieją czekała Assol: Сияющая громада альих парусов белого корабля двинется, рассекая волны, прямо к тебе (АР, 22), Много ведь придется в будущем увидеть тебя не альх, а грязных и хищных парусов; издали - нарядных и бельх, вблизи - рваных и нагльхх (AР, 24), Розовые тени скользили по белизне мачт и снастей, все было бельм, кроме раскинутых, плавно двинутых парусов ивета глубокой радости (AP, 76), «Опять жучишка ... дурак!...»- - хотела решительно сдуть гостя в траву, но вдруг случайный переход взгляда от одной крыши к другой, открыл ей на синей морской щели уличного пространства бельй корабль с альли парусами (АР, 79), Негромкая музыка лилась в голубом дне с белой палубы под огнем алого шел$\kappa a(\mathrm{AP}, 79)$. Grin, wybierając kolor dla okrętów, niewątpliwie kierował się symboliką bieli. Okręt, na który czeka Assol, zmieni jej życie na lepsze, prze- 
staną istnieć problemy, spełnią się jej marzenia i będzie początkiem nowego, szczęśliwego, beztroskiego życia.

\section{Barwa szara (серый цвет)}

Kolor szary - to kolor neutralny. Jest on interpretowany jako kolor popiołu, dymu, asfaltu i myszy, a także jako kolor pośredni między białym i czarnym 5 . Szary to symbol apatii, zmęczenia, braku siły i energii, to symbol człowieka niezauważanego i mało utalentowanego [Шейнина 2003, 367]. Szarość kojarzy się z nudą, pustką, nijakością. Połączenie białego, koloru niewinności, i czarnego, koloru winy - szary był chrześcijańskim symbolem śmierci na ziemi i duchowej nieśmiertelności [http://www.symbolarium.ru/ index.php/Серый_цвет].

Barwa szara w analizowanym utworze jest nazywana przymiotnikami серьй (7), седой (3), полуседой (1), поседевший (1) і стальной (1) oraz imiesłowem серея (1). Jest ona pozbawiona wszelkich konotacji i zostaje przywołana w opisach człowieka, przyrody i przedmiotów.

Podstawowym zakresem występowania koloru szarego są opisy człowieka. W kreowaniu językowego obrazu człowieka szarość występuje przede wszystkim jako określenie koloru włosów ludzi starszych: Cedbıe кyдpu складками выпадали из-под его соломенной шляпь; серая блуза, заправленная в синие брюки, и высокие сапоги придавали ему вид охотника; бельй воротничок, галстук, пояс, унизанный серебром блях, трость и сумка с новеньким никелевьм замочком - выказывали горожанина (AР, 18), Ему сказали, где мать: он прошел в высокое помешение и, тихо прикрьвв дверь, несльгшно остановился, смотря на поседевшую женшину в черном платье (АР, 39), Она приговаривая что-то про себя, разгладила его спутанные седые волосы (AР, 53), В раскрытом окне, на столе, виднелась бутьлка: возле нее чья-то грязная рука доила полуседой ус (AP, 47).

$\mathrm{W}$ analizowanym materiale niewiele jest przykładów użycia tej barwy do opisu odzieży. Leksem серьıu został wykorzystany tylko jako określenie koloru bluzy: Седье кудри складками вьпадали из-под его соломеннои иляпь; серая блуза, заправленная в синие брюки, и выссокие сапоги придавали ему вид охотника; бельй воротничок, галстук, пояс,

\footnotetext{
5 серый 'цвета пепла, дыма, асфальта, мыши; средний между черным и белым' [Большой толковый словарь русского языка 2000, 1180].
} 
унизанный серебром блях, трость и сумка с новеньким никелевым замочком - выказывали горожанина (AP, 18) i koloru jedwabnej chusteczki Assol: На ее плечах лежала серая шелковая косынка (AР, 54).

W jednym przypadku kolor szary został porównany do koloru piasku i wykorzystany przez Grina do opisu koloru oczu kolekcjonera piosenek, legend i bajek Egla: Его лиџо, если можно назвать личом, нос, губы и глаза, выглядывавшие из бурно разросшейся лучистой бороды и пьишных, свирепо взрогаченных вверх усов, казалось, было вяло-прозрачныл, если бы не глаза, серые, как песок, и блестящие, как чистая сталь, с взглядом смельм и сильным (АР, 20).

Sporadycznie barwa szara współtworzy językowy obraz otoczenia człowieka. W Szkartatnych żaglach pojawia się tylko w opisie książek: Pазнообразие переплетов, грубых, нежных, черных, пестрых, синих, серых, толстых, тонких, шершавых и гладких (AP, 34), і оріsie dachu domu, w którym mieszkali Assol i Longren: Дом с серой крылей, по два окна сбоку; при нем огород (AР, 68).

Wśród pól semantycznych charakteryzowanych przy pomocy szarości należy umieścić również świat przyrody. Obiektami opisywanymi przez przymiotnik серыŭ są zarówno zwierzęta: Там, на длинном столе лежали радужные фазаны, серые утки, пестрые курыг; там - свиная туша с коротеньким хвостом, и младенчески закрытыми глазами; там - репа, капуста, орехи, синий изюм, загорелье персики (AР, 30), И точно, еж, серея, покатился перед ней на тропинку (AP, 58), jak i rośliny: На камнях и на земляном полу росли серье грибы с тонкими ножками; везде - плесень, мох, сырость, кисльй, удушливый запах (AP, 28). W dwóch przypadkach barwa szara jest wykorzystana do opisu wody oceanu: Лонгрен выходил на мостик, настланный по длинным рядам свай, где, на самом конце этого дощатого мола, подолгу курил раздуваемую ветром трубку, смотря, как обнаженное у берегов дно дымилось седой пеной, еле поспевающей за валами, грохочущий бег который к черному, штормовому горизонту напомнил пространство стадами фантастических гривастых существ, несущихся в разнузданном свирепом отчаянии $\kappa$ далекому утешению (AР, 11), Стальной у берега ивет спящего океана переходил в синий и черный (AР, 59).

\section{Zakończenie}

W Szkarkatnych żaglach A. Grina kolory achromatyczne są reprezentowane przez nazwy barw trzech pól semantycznych - pola czerni, pola bieli 
i pola szarości. Najszerzej rozbudowana została biel (25 użyć), natomiast do oddania barwy szarej wykorzystana została największa liczba nazw (8 leksemów):

\begin{tabular}{|c|c|c|c|}
\hline \multicolumn{2}{|c|}{ Nazwa barwy } & \multicolumn{2}{|c|}{ Liczba wystąpień } \\
\hline Czarny & $\begin{array}{l}\text { черный } \\
\text { почерневший }\end{array}$ & $\begin{array}{r}21 \\
1\end{array}$ & 22 \\
\hline Biały & $\begin{array}{l}\text { бельий } \\
\text { белизна } \\
\text { белокурьий } \\
\text { серебряньй } \\
\text { белевший }\end{array}$ & $\begin{array}{r}19 \\
3 \\
1 \\
1 \\
1\end{array}$ & 25 \\
\hline Szary & $\begin{array}{l}\text { серый } \\
\text { седой } \\
\text { полуседой } \\
\text { стальной } \\
\text { серея } \\
\text { поседевший }\end{array}$ & $\begin{array}{l}7 \\
3 \\
1 \\
1 \\
1 \\
1\end{array}$ & 14 \\
\hline
\end{tabular}

Pisarz używa nazw barw achromatycznych najczęściej w konwencjonalny sposób i posługuje się nimi kreując świat przedstawiony. Wszystkie trzy barwy wiążą się przede wszystkim z polami semantycznymi związanymi z człowiekiem i przyrodą. Służą między innymi do opisu koloru skóry (np.: черныий человек, черная рука, белизна кожи), koloru włosów (nр.: белая коса, белокурая голова, седые кудри) oraz ubrań człowieka (nр.: черное платье, белье колпаки, серая шелковая косынка). Ta paleta barw pełni również ważną funkcję w językowym obrazie przyrody. Czerń, biel i szarość zostały wykorzystane do opisu krajobrazu morskiego (nр.: черный штормовой горизонт, белая пена, седая пена), оріsu roślin (nр.: черные с розовой тенью тюльпаны, белье шишки иветов, серые грибы) oraz zwierząt (nр.: черная собака с белой грудью, серье утки).

Badany materiał pokazuje, że stosunkowo rzadko barwy achromatyczne charakteryzują obiekty związane z otoczeniem człowieka i jego pracą. Sporadycznie tylko pojawiają się w opisie budynków (np.: почерневшие стены, серая крыша), okrętu (nр.: белое суденышко, черная линия мачты) czy książek (np.: черный переплет). 
Chociaż barwy achromatyczne najczęściej są pozbawione znaczenia symbolicznego, to tworzą jednak koloryt analizowanego utworu. Kilkakrotnie są kojarzone ze swoimi wzorcami prototypowymi: czerń symbolizuje zło (черная игрушка, черный флаг, черные лучи), а biel - niewinność (белая ямка, мезинеи, белевший из-под затылка). Wykorzystanie bieli i czerni w opisach przyrody odzwierciedla cenne pomysły autora. Natomiast pole barwy szarej (chociaż i dość obszerne) nie uczestniczy w tworzeniu żadnych obrazów symbolicznych. Kreuje tylko ogólną kolorystykę utworu.

\section{Literatura}

Berlin B., Kay P., 1969, Basic Color Terms: Their Universality and Evolution, Berkley.

http://paustovskiy.niv.ru/paustovskiy/public/volshebnik-o-grine.htm [10.09.2017]

http://www.rulit.me/books/simvoly-znaki-emblemy-enciklopediya-read-228708-19 8.html [10.08.2017]

http://www.rulit.me/books/simvoly-znaki-emblemy-enciklopediya-read-228708-2 4.html [10.08.2017]

http://www.symbolarium.ru/index.php/Серый_цвет [15.09.2017]

Komorowska E., 2010, Barwa w jezzyku polskim i rosyjskim. Rozważania semantyczne, Szczecin.

Pollak S., 1959, Geograf krajów urojonych, [w:] A. Grin, Piekło odzyskane, Warszawa, s. V-XIX.

Tokarski R., 2004, Semantyka barw we wspótczesnej polszczyźnie, Lublin.

Bol'šoj tolkovyj slovar' russkogo âzyka, 2000, gl. red. S.A. Kuznecov, Sankt-Peterburg. [Большой толковый словарь русского языка, 2000, гл. ред. С.А. Кузнецов, Санкт-Петербург.]

Grin A.S., 1999, Alye parusa, Moskva. [Грин А.С., 1999, Aльеe napyca, МоскBa.] - (AP)

Mel'nikova L.A., 2009, A.S. Grin: slovo - obraz, Minsk. [Мельникова Л.А., 2009, А.С. Грин: слово - образ, Минск.]

Šejnina E.Â., 2003, Ėnciklopediâ simvolov, Moskva. [Шейнина Е.Я., 2003, Энциклопедия символов, Москва.]

\section{ACHROMATIC COLOR PALETTE IN SCARLET SAILS BY ALEXANDER GRIN}

S U M M A R Y

The object of the analysis are achromatic color names in Scarlet sails of Alexander Grin. Color expressions are an inseperable part of the world description. 
The researched material provides valuable information about the models of perception, association and interpretation of the world presented in the novel.

The field of black color is represented by adjectives, such as, черньий, nочерневший, the field of white is represented by lexemes бельй, белизна, белокурый, белевший, серебряный, and field of grey - by lexemes серьй, седой, полуседой, стальной, серея, поседевший. These are relatively richly represented fields.

The studied material shows that the writer mostly uses the achromatic color names in a conventional way and uses them to create the presented world. All three colors are mainly connected with semantic fields related to man and nature. The objects related to human environment and work are characterized by achromatic colors relatively rarely. 